\title{
Bioinorganic Chemistry of Co (II) and Mn (II) Complexes
}

\author{
Vinay Kumar Srivastava \\ Department of Chemistry, DS College, Aligarh, Uttar Pradesh, INDIA.
}

\begin{abstract}
Objectives: Schiff base ligand 2-thio phenyl glyoxal anthranilic acid is used as the starting material for the synthesis of many biologically active compounds. The main objectives of the Study was to synthesize, characterization and biological evaluation of a octahedral complexes of $\mathrm{Co}$ (II) and $\mathrm{Mn}$ (II) containing 2- thiophenyl glyoxal anthranilic acid as ligand. Methods: Ethanolic solution of ligand 2-thiophenyl glyoxal anthranilic acid added into the ethanolic solution of metal acetate the resulting solution was refluxed for $2 \mathrm{hr}$ the product thus obtained was filtered, washed with ethanol followed by ether and characterized by various spectral studies and biological significance. Results: The resulted complex was investigated by the help of elemental analysis, Molar Conductance, Magnetic moment, $I R$, Electronic and NMR Spectral Studies. Spectral data indicates that the geometry of the complexes are Octahedral. The result of biological
\end{abstract}

and cytotoxic studies indicate that complexes are much more biologically active as compared to ligand fragments. Conclusion: The complexes are biologically active and were found to be effective in all the human cancer cell lines.

Key words: Antimicrobial, Cytotoxicity, Enzyme inhibition, Spectra, Synthesis.

\section{Correspondence}

Dr. Vinay Kumar Srivastava

Department of Chemistry, D.S. College, Aligarh, Uttar Pradesh, INDIA.

Phone no: +919457192232

Email: vkschemistrydscollege@gmail.com

DOI: 10.5330/ijpi.2020.3.49

\section{INTRODUCTION}

Schiff bases containing penicillin and heterocyclic structural units with $\mathrm{N}, \mathrm{N}$ donor atoms are considered the most prominent research area in the field of coordination chemistry. ${ }^{1-6}$ The various donor atoms in them offer special ability for binding metals. Schiff base change the physiological, morphological and pharmacological activities of the compounds. Schiff base complexes have been used as drugs and have valuable antibacterial antifungal, anti-inflammatory and antitumor activities. A large number of Schiff bases and their complexes have been studied for their interesting and important properties e.g. their ability to reversibly bind oxygen, catalytic activity in hydrogenation of olefins and transfer of an amino group photochromic properties. The high affinity for the chelation of the Schiff bases towards the transition metal ions is utilized in preparing their solid complexes. In the present paper the Co (II) and Mn (II) complexes were synthesized with Schiff base ligand 2-Thio phenyl glyoxal anthranilic acid (TGAA). The coordination behavior of the ligand towards transition metal irons was fully investigated by various spectral techniques. Biochemical Behavior of the complexes were evaluated by antimicrobial, Enzyme inhibition activity and cytotoxic studies.

\section{MATERIALS AND METHODS}

\section{Materials}

All the Chemicals used were of analytical reagent grade and the solvents were dried and distilled before use according to a standard procedure. The organic solvents DMSO, DMF, Ethanol and Ether were of analytical reagent grade and used as such without further purification.

\section{Methods}

\section{Synthesis of complexes}

An ethanolic solution of ligand 2-Thiophenyl glyoxal anthranilic acid (TGAA) prepared by dissolving $1.04 \mathrm{~g}$ ligand in $60 \mathrm{~mL}$ ethanol was added to $30-40 \mathrm{~mL}$ ethanolic solution of Metal acetate $0.50 \mathrm{~g}$ Co $(\mathrm{OAC})_{2} 4 \mathrm{H}_{2} \mathrm{O} / 0.40 \mathrm{~g} \mathrm{Mn}(\mathrm{OAC})_{2} 4 \mathrm{H}_{2} \mathrm{O}$ in round bottom flask. The resulting solution was refluxed over a water bath for about $2 \mathrm{hr}$. and cooled. The separated coloured products were filtered through suction, washed with ethanol followed by ether and dried in Vacuum over anhydrous $\mathrm{CaCl}_{2}$.

$$
\begin{array}{cc}
\text { Yield } & \\
\mathrm{Co}\left[\mathrm{C}_{13} \mathrm{H}_{8} \mathrm{O}_{3} \mathrm{NS}\right]_{2} & 65 \% \\
\mathrm{Mn}\left[\mathrm{C}_{13} \mathrm{H}_{8} \mathrm{O}_{3} \mathrm{NS}\right]_{2} & 70 \%
\end{array}
$$

\section{Instrumentations}

$\mathrm{C}, \mathrm{H}, \mathrm{N}$ were analyzed on carlo-Erba microanalyzer Model 1106 Metal contents estimated by standard procedures 7 IR spectra were recorded in the range $4000 \mathrm{~cm}^{-1}-100 \mathrm{~cm}^{-1}$ with a Bruker IFS66V in $\mathrm{KBr}$ and Polyethylene medium for all complexes. The Molar conductance of the complexes in DMF (10-3M) solution was measured at $27+3^{\circ} \mathrm{C}$ with an Elico Model Conductivity meter. Electronic spectra of the complexes were recorded on varian cary- 5E UV-Visible spectrophotometer NMR spectra were recorded or Bruker $300 \mathrm{~Hz}$ spectrophotometer using DMSO d6 as solvent chemical Shifts are reported in ppm relative to tetramethyl silane using the solvent signal as internal reference. The Magnetic moment measurement were mode on a Gouy Balance at room temperature using $\mathrm{Hg}[\mathrm{Co}(\mathrm{SCN}) 4]$ as the Calibrant.

\section{Biological activities \\ Antimicrobial activity}

The Schiff base ligand and its complexes were investigated for antibacterial and antifungal activities against Staphylococcus aureus and Streptococcus pyogenes as gram positive bacteria and Escherichia coli and Klebsiella pneumoniae as gram negative and 
the Fungi Fusarium oxysporum and as Aspergillus fumigatus by using disc agar diffusion method.

The antibiotic chloramphenicol and tetracycline were used as standard reference in the case of Gram-negative and Gram-positive bacterial species, whereas Clotrimazole was used as standard reference for fungal species incubation time for $36 \mathrm{~h}$ at $27^{\circ} \mathrm{C}$ in the case of bacteria and for $48 \mathrm{~h}$ at $24^{\circ} \mathrm{C}$ in the case of fungus, inhibition of the organism which evidenced by clear zone surround each disk was measured and used to calculate men of inhibition zone.

\section{Enzymatic activity}

Enzymatic activity is carried out by cup-plate method. All the plates were incubated at $30^{\circ} \mathrm{C}$ for $48 \mathrm{hr}$ in BOD incubator. The activity zone of the produced enzyme after incubation was developed by flooding the plates with an appropriate developing agent. The total diameter of zone of inhibition in $\mathrm{mm}$ was measured and the activity was calculated.

\section{Cytotoxic studies}

Further the synthesized metal complexes have been evaluated for their cytotoxic activity against a panel of different human cancer cell lies by using MTT (3-(4)5- dimethyl thiazole-2-yl)2,5- di phenyl tetrazolium bromide) assay.

\section{RESULTS}

\section{Selection of ligand}

Metal complexes with a variety of organic chelating ligand are also of current interest due to their biological activities. These include antimicrobial, enzymatic activity and cytotoxic studies.

The required amount of ligand 2-thiophenyl glyoxal anthranilic acid in ethanol was added to the ethanolic solution of Cobalt acetate/ Manganese acetate refluxed for $2 \mathrm{hr}$, The coloured product thus obtained were filtered washed with ethanol followed by ether and dried. Finally characterized by elemental analysis, molar conductance and spectral studies. The spectral datas indicates that the geometry of complexes are Octahedral and Biological studies showed that metal complexes are much more active as compared to ligand fragments.

\section{Characterization of free ligand and its metal complexes}

Elemental analysis, Molar Conductance and Melting point/ Decomposition temperature

In Table 1, The elemental analysis results (C.H,N,M), Melting point/ Decomposition temperature, The Molar Conductance of ligand and metal complexes.

\section{IR Spectral Studies}

Infrared spectra of free ligand shows a sharp band in the region of $1615-1590 \mathrm{~cm}^{-1}$ which may be attributed due to the stretching vibration of azomethine group $(>\mathrm{C}=\mathrm{N})$. This band is shifted towards lower frequency region in the spectra of metal complexes. Suggesting thereby the participation of imine nitrogen in complexation A strong band in the region $1730-1680 \mathrm{~cm}^{-1}$ has been observed in the IR spectra of ligand which in due to the presence of stretching vibration of carbonyl group $(>\mathrm{C}=\mathrm{O})$ coordination through this carbonyl oxygen to the central metal ion is confirmed by a negative Schiff in this frequency in the spectra of corresponding metal complexes. ${ }^{8-10}$

\section{Electronic spectral Studies}

In octahedrally surrounded $\mathrm{Co}$ (II) ions three bands in the region of $8000,16000-13500$ and $20000-17600 \mathrm{~cm}^{-1}$ are expected which may be assigned to $4 \mathrm{~T}_{1 \mathrm{~g}} \rightarrow{ }^{4} \mathrm{~T}_{2 \mathrm{~g}}(\mathrm{~F}) \mathrm{v}_{1,}{ }^{4} \mathrm{~T}_{1 \mathrm{~g}} \rightarrow 4 \mathrm{~A}_{2 \mathrm{~g}}(\mathrm{~F}) \mathrm{v}_{2}$ and
${ }^{4} \mathrm{~T}_{1 \mathrm{~g}} \rightarrow{ }^{4} \mathrm{~T}_{1 \mathrm{~g}}(\mathrm{P}) \mathrm{v}_{3}$ Transition respectively. The ${ }^{4} \mathrm{~A}_{2 \mathrm{~g}}$ Transition is very weak and often appears as a shoulder The Mn (II) complex shows three bands at $17000,2500,29800 \mathrm{~cm}^{-1}$ These spectral bands are assigned as the ${ }^{6} \mathrm{~A}_{1 \mathrm{~g}} \rightarrow{ }^{4} \mathrm{~T}_{1 \mathrm{~g}} \rightarrow{ }^{6} \mathrm{~A}_{1 \mathrm{~g}} \rightarrow{ }^{4} \mathrm{~T}_{2 \mathrm{~g}}$ and charge transfer (CT) respectively. ${ }^{11-16}$

\section{NMR Spectral Studies}

${ }^{1} \mathrm{H}$ NMR spectra of free Schiff base the signals were appeared in the range of $8.10-8.24 \mathrm{ppm}$ due to $(\mathrm{HC}=\mathrm{N})$ proton however in the spectra of $\mathrm{Co}(\mathrm{II})$ and $\mathrm{Mn}$ (II) complexes the signals were observed in the upfield region of $8.25-8.34$ ppm supporting the coordination of iminonitrogen atom to $\mathrm{Co}$ (II)/ $\mathrm{Mn}$ (II). There is no appreciable change in the Peak position corresponding to $\mathrm{NH}$ and aromatic proton. The ${ }^{13} \mathrm{C}$ NMR signals for the metal complexes of Co (II) and Mn (II) ions are assigned by the comparison with the spectra of corresponding free Schiff base ligand. A down field shift of $\mathrm{CH}=\mathrm{N}$ group in the range of 172.6-174.5 ppm and for carboxyl carbon $\mathrm{COO}^{-}$ion in the range of 192.6 - 195.4 ppm. ${ }^{17}$ The NMR spectra of complexes indicates that the ligand coordinates through both the nitrogen atom of $\mathrm{CH}=\mathrm{N}$ and the oxygen of $\mathrm{COO}^{-}$ion

\section{Biological activity Enzyme inhibition activity}

A comparative study of enzyme activity of the ligand and their metal complexes indicate that the enzyme activity of the ligand has considerably increased in the form of metal complexes. The ligand and metal complex play an competitive role with the substrate required for their production and thus the free availability of the substrate in reduced inhibiting the growth. ${ }^{18-20}$ The results are given in Table 2 and Table 3.

Ligand/ metal complexes of $\mathrm{Co}$ (II) and $\mathrm{Mn}$ (II) on diffusion inside cells affect their Mitochondrial action causing a death to them. There could be a ligand or metal exchange reaction on diffusion of these species insides the cells, Thus rapturing the cell structure Ligand may be more toxic to the enzymatic cell in combination with Metal ions vice-versa. It is evident from Table 3 that the bacteria Staphylococcus aureus produced cellular, Protease and amylase in liquid culture medium containing three different specific at the optimum $\mathrm{pH}$ values of their production the order of production of these enzymes under identical experimental conditions has been observed as Amylase $>$ Protease $>$ cellulose.

\section{Antimicrobial Activity}

The free ligand and metal complexes were evaluated against bacterial and fungal species. The results are given in Table 4 .

Metal chelates bear polar and non-polar properties together this makes them suitable for permeation to the cells and tissues. In addition, chelation may enhance or suppress the bio-chemical potential of bioactive organic species. Changing hydrophobicity and lipophilicity probably leads to bringing down. The solubility and permeability barriers of cell Further lipophilicity which control the rate of entry of molecules into the cell in modified by coordination so the metal complexes can become more active than free ligand. Chelation considerably reduces the polarity of the Metal ion because of particular sharing of its positive charge with donor groups and possible electron delocalization over the whole chelate ring as a result the lipophilicity of Metal complexes enhances the Penetration of the complexes into lipid membranes and blocking of the Metal binding sides in the enzymes of micro-organisms. These complexes also disturb the respiration process of the cell and thus block the synthesis of the Proteins that restricts further growth of the organism. ${ }^{21-23}$ 
Table 1: Physical and analytical data of synthesized compounds.

\begin{tabular}{|c|c|c|c|c|c|c|c|c|c|}
\hline S.No. & Compound & $\begin{array}{l}\text { Molecular } \\
\text { Formula }\end{array}$ & Colour & $\begin{array}{c}\text { \%Analysis } \\
\text { C }\end{array}$ & $\begin{array}{c}\text { Found/Calc } \\
\mathrm{H}\end{array}$ & N & $M$ & $\begin{array}{c}\text { MP } \\
\text { (OC) / } \\
\text { Decom } \\
\text { Temp. }\end{array}$ & $\begin{array}{l}\text { Molar } \\
\text { Conductace } \\
(\Omega) \text { ohm }^{-1} \\
\mathrm{~cm}^{2} \mathrm{~mol}^{-1}\end{array}$ \\
\hline 1 & TGAA & $\mathrm{C}_{13} \mathrm{H}_{9} \mathrm{O}_{3} \mathrm{~N}_{\mathrm{s}}$ & $\begin{array}{c}\text { Orange } \\
\text { Red }\end{array}$ & $\begin{array}{c}60.40 \\
(60.23)\end{array}$ & $\begin{array}{c}3.63 \\
(3.47)\end{array}$ & $\begin{array}{c}5.56 \\
(5.41)\end{array}$ & - & $187-190$ & - \\
\hline 2 & $\mathrm{Co}[\mathrm{TGAA}]$ & $\mathrm{Co}\left[\mathrm{C}_{13} \mathrm{H}_{8} \mathrm{O}_{3} \mathrm{NS}\right]_{2}$ & Green & $\begin{array}{c}54.17 \\
(54.27)\end{array}$ & $\begin{array}{c}2.63 \\
(2.78)\end{array}$ & $\begin{array}{c}4.64 \\
(4.87)\end{array}$ & $\begin{array}{c}10.39 \\
(10.25)\end{array}$ & 302 & 9.02 \\
\hline 3 & $\mathrm{Mn}[\mathrm{TGAA}]$ & $\mathrm{Mn}\left[\mathrm{C}_{13} \mathrm{H}_{8} \mathrm{O}_{3} \mathrm{NS}\right]_{2}$ & Red & $\begin{array}{c}60.40 \\
(60.46)\end{array}$ & $\begin{array}{c}3.18 \\
(3.10)\end{array}$ & $\begin{array}{c}5.00 \\
(5.42)\end{array}$ & $\begin{array}{c}10.59 \\
(10.63)\end{array}$ & 295 & 6.29 \\
\hline
\end{tabular}

Table 2: Substrate used for the Production of enzymes, their optimum $\mathrm{pH}$, developing agent and color of the developed zone

\begin{tabular}{cccccc}
\hline S.No. & $\begin{array}{c}\text { Enzyme } \\
\text { Produced }\end{array}$ & $\begin{array}{c}\text { Substrate } \\
\text { Used }\end{array}$ & $\begin{array}{c}\mathrm{pH} \text { of the } \\
\text { Medium }\end{array}$ & $\begin{array}{c}\text { Developing } \\
\text { Agent }\end{array}$ & $\begin{array}{c}\text { Colour } \\
\text { of } \\
\text { Deloped } \\
\text { Zone }\end{array}$ \\
\hline 1. & Cellulose & $\begin{array}{c}\text { Carboxy } \\
\text { methyl } \\
\text { Cellulose }\end{array}$ & 5.3 & $\begin{array}{c}3 \% \text { Lead } \\
\text { Actual Soluion }\end{array}$ & $\begin{array}{c}\text { Pearl } \\
\text { White }\end{array}$ \\
2. & Protease & Gelatin & 6.8 & -- & $\begin{array}{c}\text { Opal } \\
\text { Black } \\
\text { Ground }\end{array}$ \\
& Amylase & Starch & 5.3 & 0.1 N Solution \\
of Iodine & $\begin{array}{c}\text { Violet } \\
\text { Black } \\
\text { Ground }\end{array}$ \\
\hline
\end{tabular}

Table 3: Enzyme inhibition Activity (in $\mathrm{mm}$ ) of synthesized compound at $30^{\circ} \mathrm{C}$ after $48 \mathrm{hrs}$

\begin{tabular}{ccccc}
\hline S.No. & Compound & \multicolumn{3}{c}{ Enzyme } \\
\hline & & Cellulose & Protease & Amylase \\
\hline 1. & TGAA (L) & 3.0 & 4.0 & 7.0 \\
2. & $\mathrm{Co}\left[\mathrm{C}_{13} \mathrm{H}_{9} \mathrm{O}_{3} \mathrm{NS}\right]_{2}$ & 1.0 & 2.0 & 3.0 \\
3. & $\mathrm{Mn}\left[\mathrm{C}_{13} \mathrm{H}_{9} \mathrm{O}_{3} \mathrm{NS}\right]_{2}$ & 1.0 & 2.0 & 4.0 \\
\hline
\end{tabular}

Table 5: Half Maximum inhibitory concentration of synthesized Metal complexes $\mathrm{IC}_{50}(\mathrm{a})$ values expressed in $\mu \mathrm{M}$

\begin{tabular}{cccc}
\hline Compound & MCF-7 $^{(\text {b) }}$ & OVCAR-3 $^{(\mathrm{c})}$ & HT- 29 (d) \\
\hline $\mathrm{Co}\left[\mathrm{C}_{13} \mathrm{H}_{8} \mathrm{O}_{3} \mathrm{NS}\right]_{2}$ & 1.62 & 2.50 & 4.58 \\
$\mathrm{Mn}\left[\mathrm{C}_{13} \mathrm{H}_{8} \mathrm{O}_{3} \mathrm{NS}\right]_{2}$ & 8.24 & 9.46 & 10.20 \\
Doxorubicin & 1.73 & 1.12 & 1.01 \\
\hline
\end{tabular}

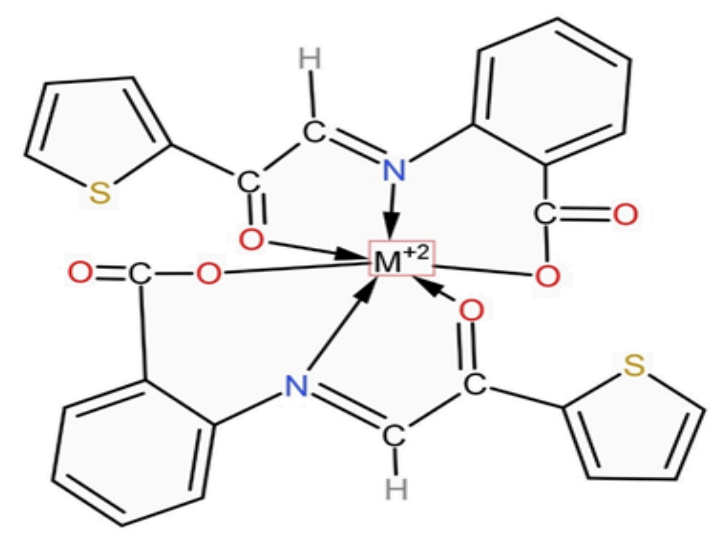

Figure 1: Chemical Structure of Metal Complex. $M=M n$ (II)/Co (II).

Table 4: Antimicrobial activities of Ligand and Metal complexes inhibition zone in $\mathrm{mm}$ concentration $100 \mu \mathrm{g} / \mathrm{mL}$

\begin{tabular}{|c|c|c|c|c|c|c|c|}
\hline \multirow[t]{2}{*}{ S.No. } & \multirow[t]{2}{*}{ Test Compound } & \multicolumn{2}{|c|}{$\begin{array}{c}\text { Gram-positive } \\
\text { Bacteria }\end{array}$} & \multicolumn{2}{|c|}{$\begin{array}{c}\text { Gram-negative } \\
\text { Bacteria }\end{array}$} & \multicolumn{2}{|c|}{ Fungi } \\
\hline & & S. aureus & S. pyogenies & E. coli & K. pneumoniae & F. oxysporum & A. fumigatus \\
\hline 1. & Tetracycline & 27 & 25 & -- & -- & -- & -- \\
\hline 2. & Chloramphenicol & -- & -- & 30 & 28 & -- & -- \\
\hline 3. & Clotrimazole & -- & -- & -- & -- & 22 & 23 \\
\hline 4. & Ligand (TGAA) & 10 & 12 & 12 & 12 & 08 & 10 \\
\hline 5. & $\mathrm{Co}\left[\mathrm{C}_{13} \mathrm{H}_{8} \mathrm{O}_{3} \mathrm{NS}\right]_{2}$ & 22 & 18 & 20 & 17 & 13 & 13 \\
\hline 6. & $\mathrm{Mn}\left[\mathrm{C}_{13} \mathrm{H}_{8} \mathrm{O}_{3} \mathrm{NS}\right]_{2}$ & 11 & 14 & 16 & 17 & 14 & 10 \\
\hline
\end{tabular}




\section{Cytotoxic Studies}

Preliminary screening of the synthesized metal complexes was carried out for their cytotoxic activity against a panel of selected human cancer cell lines such as MFC -7 (Breast), OVCAR-3 (ovarian) and HT-29 (Colon) by using MTT assay. ${ }^{24-27}$ The result of this cytotoxic testing expressed as $\mathrm{IC}_{50}$ values is summarized in Table 5 Doxorubicin was used as a positive control. $\mathrm{Co}(\mathrm{II})$ and $\mathrm{Mn}$ (II) complexes were found to be effective in all the cell lines examined.

\section{DISCUSSION}

The elemental analysis and metal estimation of the complex led to the formula $\mathrm{M}\left[\mathrm{C}_{13} \mathrm{H}_{8} \mathrm{O}_{3} \mathrm{NS}\right]_{2}$ where $\mathrm{M}=\mathrm{Mn}$ (II)/Co (II).The experimental values are in good agreement with the theoretical values (given in parentheses). The low molar conductance values indicate that the complexes are non-electrolytic nature. IR spectra of ligand (TGAA) show a band of medium intensity in the region of $3500-3470 \mathrm{~cm}^{-1}$ due to the $-\mathrm{OH}$ stretching vibration of free- $\mathrm{CO}_{2} \mathrm{H}$ group coordination of ligand as a consequence of deprotonation of $-\mathrm{CO}_{2} \mathrm{H}$ group is evident by the disappearance of the above band in the IR spectra of respective metal complexes. Furthermore the asymmetrical and symmetrical vibrations of COO group appear at $1560-1530 \mathrm{~cm}^{-1}$ and $1340-1320 \mathrm{~cm}^{-1} \Delta v$ (as-s) value $220-210 \mathrm{~cm}^{1}$ indicate the coordination through unidentate carboxylate group. Some New bands appeared in the IR spectra of metal complexes in the regin of $550-530 \mathrm{~cm}^{-1} 450-430 \mathrm{~cm}^{-1}$ and $335-325 \mathrm{~cm}^{-1}$ are probably due to formation of $\mathrm{M}-\mathrm{O}, \mathrm{M}-\mathrm{N}$ and $\mathrm{M}-\mathrm{S}$ respectively. On the basis of electronic spectral studies The Magnetic moment values of the $\mathrm{Co}(\mathrm{II})$ and $\mathrm{Mn}$ (II) complexes are 4.60 and 5.05 B.M. suggesting octahedral geometry. The free ligand NMR spectra has a characteristic NMR signal for carboxyl group proton in the 10.17-10.80 ppm range, the disappearance of this signal in the ${ }^{1} \mathrm{H}$ NMR spectra of metal complexes indicating the involvement of Carboxylate ion oxygen in chelation through deprotonation.

\section{Suggested structure of the Complex}

The proposed structure of complex based on the above mentioned physico-chemical, Spectral studies like elemental, molar conductance, magnetic moment, IR, Electronic, NMR. The tentative structure of the complex is shown in Figure 1. A comparative study of enzyme activity of the ligand and their respective metal complexes indicate that the enzyme activity of the ligand has considerably increased in the form of metal complexes. The ligand/ metal complexes play a competitive role with the substrate required for their production and thus the free availability of the substrate in reduced inhibiting the growth. The result of antimicrobial activity of the ligand and its metal complexes of $\mathrm{Co}(\mathrm{II})$ and $\mathrm{Mn}$ (II) indicate that complexes show more activity and the ligand has less activity against microorganism. The higher cytotoxic activity of Cobalt complex than Manganese complex may be attributed to the function of the Cobalt complex as a competitive inhibitor of Hemeoxygenase which is produced in large amounts in solid tumors in humans and animal tumor thus cobalt complex has the capacity to reduce the energy status in tumors as well as to enhance tumor hypoxia which also influences its antitumor activity probably through Cobalt biomolecule interaction. ${ }^{28-30}$

\section{CONCLUSION}

Schiff base and its $\mathrm{Co}(\mathrm{II})$ and $\mathrm{Mn}(\mathrm{II})$ complexes were prepared and characterized using the micro-analytical, conductance spectral analysis which reveal that ligand coordinating through the azomethine nitrogen and carbonyl oxygen atoms. The geometry of the complexes is assigned as octahedral. The complexes are biologically active and showed enhanced antimicrobial, Enzyme inhibition activity compared to the free ligand.
Synthesized metal complexes were also found to be effective in all the human cancer cell lines.

\section{ACKNOWLEDGEMENT}

The author is greatly thankful to SAIF CDRI Lucknow, SAIF Chennai and SAIF Cochin India for providing Physico-Chemical and Biological Studies.

\section{CONFLICT OF INTEREST}

The author declares that there is no conflict of interest.

\section{ABBREVIATIONS}

DMSO: Dimethylsulfoxide; DMF: Dimethylformamide; IR: Infrared Spectra UV: Ultraviolet Spectra; NMR: Nuclear Magnetic Resonance Spectra; BOD: Biological Oxygen Demand; PPM: Parts Per Million

\section{REFERENCES}

1. Gulcan M, Ozdemir S, Dundar A, Ispir E, Kurtoglu M. Mononuclear complexes based on Pyrimidine ring azo Schiff base ligand. J Inorganic General Chem. 2014;(640):1754-62.

2. Nair MS, Arish D, Joseyphus RS. Synthesis, characterization, antifungal, antibacterial and DNA cleavage studies of some hetrocyclic Schiff base metal complexes. Journal of Saudichemical Society. 2012;16(1):83-5.

3. Zoubi WAL, Hamdani AAS, Kaseem M. Synthesis and antioxidant activities of Schiff bases and their complexes: A review. Appl Organomet Chem. 2016;30(10):810-7.

4. Lindoy LF. Metal ion control in the synthesis of Schiff base complexes quarterly. Rev Chem Society. 1971;25(3):379-91

5. Yamada S. Recent aspects of the stereochemistry of Schiff base metal complexes. Coord Chem Rev. 1966;1(4):415-37.

6. Kumar S, Dhar DN, Saxena PN. Applications of metal complexes of Schiff bases a review. Journal of Scientific and Industrial Research. 2009;68(3):181-7.

7. Vogal Al. Text Book of Practical organic chemistry, fifth ed. Longman, London. 1989.

8. Nakamoto K. Infrared and Raman spectra of Inorganic and coordination compounds New York Wiley $3^{\text {rd }}$ edn. 1997.

9. Thankmony M, Mohaman K. Synthesis, Spectral Studies, Thermal decomposition Kinetics, reactivity and antibacterial activity of Some Lanthanide (III) nitrate. Complexes Indian J Chem. 2007;A(46):249.

10. Thomas M, Nair MK, Radha K. Synth React Inorg Met-Org. Chem. 1995;25:471

11. Lever ABP, Inorganic electronic spectroscopy New York Elsevier $2^{\text {nd }}$ edn. 1968.

12. Farmer, RL and Urbach, FL. Synthesis and Characterization of the metal complexes with tetradentate Schiff base ligands. Inorg Chem.1974;13:587.

13. Tas E, Aslanoglu M, Kilic A, Kara Z Synthesis, Spectroscopic and electrochemical Studies of Cu(II) and Co(II) Complexes. J Coord Chem. 2006;59(8):861-72.

14. Sathyanaryana DN. Electronic Absorption Spectroscopy and related technique. University Press India. 2001.

15. Quraishy A, Ahmad S. Synthesis, Characterization and antimicrobial Studies of Ti (III), Mn(II), Cu(II) Complexes with Semicarbazones. J Ind Chem Soc. 2005:82 (6):553-4

16. Li BW, Zhou YL, Chem Q, Zeng MH,Synthesis and Characterization of transition metal complexes. Polyhedron. 2010;29:148-53.

17. Limington RG, Williams PG, Machmillan JB. A Practical approach. To NMR Spectroscopy. CRC Press. 2015. ISBN 978-1149871629

18. Winder CV, Wax JW. Enzyme inhibition activity of metal Complexes. J Pharmacol Exptl Therap.1961;133:117.

19. Freeman PC, Goudie AC, Mangan FR, Thomson M.The role of Copper in preventing gastrointestinal damage by acidic anti-inflammatory drugs. J Pharm Pharmacol.1976;28:865-8

20. Sorenson, JR Copper Chelates as possible active forms of the antiarthritic agents. J Med Chem.1976;19:135.

21. Gross DC, De Vay SC. Production and purification of syringomycin a phytotoxin produced by pseudomonas syringal. Physiol Plant Pathol.1977;11:13.

22. Sonmez M, Metin C. Berber I. Synthesis, spectroscopic and biological studies on the new symmetric Schiff base derived from 2.6-diformyl-4-methylphenol with N-aminopyrimidine. Eu J Med Chem. 2010;45:1935

23. Kurtomg L, Dagdelen MM, Torg S. Antimicrobial activity of Schiff base metal complexes. Trans Met Chem. 2006;31:382.

24. Mueller H. Kassack MU, Wiese M. Comparison of the usefulness of the MTT ATP and calcein assays to predict the potency of cytotoxic agents in various human cancer cell lines. J Biomol Screen. 2004;9(6):506-15. 
25. Mosmann T. Rapid Colorimetric assay for cellular growth and survival: application to proliferation and cytotoxicity assays. J Immunol Methods. 1983;65(1-2):5563.

26. Nastasa C, Vodnar D, lonut I. Antibacterial evaluation and virtual screening of new thiazolyltriazole Schiff bases as potential DNA-gyrase inhibitors. Int J Mo Sci. 2018;18(1):177.

27. Singh AP, Kaushik NK, Verma AK, Hundal G, Gupta R. Synthesis, structure and biological activity of Cu(II) complexes. Eur J Med Chem. 2009;44:1607.
28. Verma AK, Bansal S, Singh J, Tiwari RK, Kasi Sankar V, Tandon V, Chandra RSynthesis and invitro cytotoxicity haloderivatives of noscapine. Bio Org Med Chem. 2006;14:6733.

29. Zheng LW, Wub LL, Zhao BX, Dong WL, Miao Jy. Synthesis of novel substituted pyrazole-5-carbohydrazide hydrazine derivatives and discovery of a potent apoptosis inducer in lung cancer cells. Bio Org Med Chem. 2009;17:1957.

30. Shen J, Liu M, Xu J, Sun B, Xu H, Zhang W.Schiff base and their derivatives as potential anticancer agents. Life Sci. 2019;(220):127-35.

Article History: Submission Date : 13-04-2020; Revised Date : 04-06-2020; Acceptance Date : 06-08-2020.

Cite this article: Srivastava VK. Bioinorganic Chemistry of Co (II) and Mn (II) Complexes. Int. J. Pharm. Investigation, 2020;10(3):268-72 